\title{
Article
}

\section{The Fall and Rise of State Capabilities in the Management of the UK Nuclear Legacy}

\author{
Haraldsen, Stephen \\ Available at http://clok.uclan.ac.uk/24216/ \\ Haraldsen, Stephen ORCID: 0000-0002-2071-1737 (2019) The Fall and Rise of \\ State Capabilities in the Management of the UK Nuclear Legacy. International \\ Journal of Public Administration, 49 (11). pp. 918-928. ISSN 0190-0692
}

It is advisable to refer to the publisher's version if you intend to cite from the work. http://dx.doi.org/10.1080/01900692.2018.1523188

For more information about UCLan's research in this area go to http://www.uclan.ac.uk/researchgroups/ and search for < name of research Group>.

For information about Research generally at UCLan please go to http://www.uclan.ac.uk/research/

All outputs in CLoK are protected by Intellectual Property Rights law, including Copyright law. Copyright, IPR and Moral Rights for the works on this site are retained by the individual authors and/or other copyright owners. Terms and conditions for use of this material are defined in the policies page.

\section{CLoK}

Central Lancashire online Knowledge www.clok.uclan.ac.uk

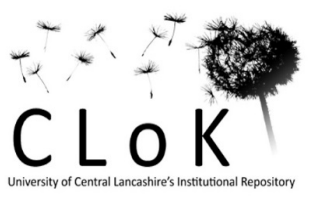




\title{
The Fall and Rise of State Capabilities in the Management of the UK Nuclear Legacy
}

Stephen Haraldsen

University of Central Lancashire, Samuel Lindow Building, Westlakes Science and Technology Park, Moor Row, Cumbria, CA24 3JZ, UK

\section{SHaraldsen@uclan.ac.uk}

+44(0) 1946517233

September 2018 - Accepted for publication - International Journal of Public Administration

\begin{abstract}
In 2015 and 2017, two large contracts for nuclear decommissioning were terminated early by the UK Government. Rather than re-tender, Government took direct ownership and control of Sellafield and began an inquiry into other sites' management. The problems with the contract model for management of the UK's nuclear legacy stem from an inability to adequately specify contracts in uncertain environments. The embrace of management and operations contracts for all sites after nationalised ownership limited the range of 'tools' to manage the nuclear legacy. This highlights the role of state capabilities alongside incentivised private sector relationships in contemporary governance.
\end{abstract}

Keywords: Nuclear, Sellafield, Decommissioning, Governance

\section{Introduction}

The United Kingdom was one of the first nations to develop military and civilian uses of atomic energy. This pioneering development made the UK the third nation to possess 
atomic weapons, and the first to open a civilian power-producing atomic power station. However, pioneering achievements of the 1950s have become significant financial, environmental and radiological hazards in the 2000s. Throughout the majority of this time the UK nuclear industry was state owned and operated, but in 2002 government signalled its intention to radically alter the governance of the industry to create "competitive markets for clean-up contracts" which government believed would "stimulate innovation and improvements in safety and operating standards" by drawing upon the best available skills across the globe (DTI 2002: 13). However, two issues complicated the involvement of private companies in the resolution of the nuclear legacy; firstly, a straightforward privatisation was tried in the 1980 s and failed due to the unquantifiable financial risks (Rhodes et al 2014: 35); and, secondly the requirement for the regulatory licence to operate the nuclear site to be non-transferrable between companies means that at each site the operator, the Site Licence Company, must be an enduring entity (NDA 2011a: 2.2). To overcome these issues and facilitate the involvement of private companies, government had to retain ownership of the sites (and ultimately the risks) and transfer ownership of the site licence companies as enduring entities. This required a new structure of governance for the nuclear legacy to be implemented, which drew heavily on the Management and Operations (M\&O) contracts used in the nuclear industry the United States. In a 2002 White Paper government signalled its intention to split the ownership and management of the nuclear legacy (DTI 2002). The Energy Act 2004 gave legal force to a new non-departmental public body, the Nuclear Decommissioning Authority, which took ownership of the sites and competitively tendered for the ownership of the companies at each site.

The most complex nuclear site in the UK is the Sellafield site in Cumbria in the North West of England. It is home to the UK's first nuclear reactors, and subsequently became a site encompassing the entire 'closed' nuclear fuel cycle, including facilities for the reprocessing of spent nuclear fuel, manufacture of new fuel and management of the hazardous wastes produced. The result is one of the most complex nuclear sites in the world and a technically 
difficult, expensive and environmentally hazardous decommissioning challenge. Due to an unforeseen set of circumstances, explored in more detail later, rather than being one of the last sites in the UK to be competitively contracted as anticipated, Sellafield became the second. It also became the first site where the contracting out of the management and operation was to be reversed. The NDA developed a new governance architecture to remove the private ownership of the site and return Sellafield to direct governmental control, but facilitate private sector involvement in the operation of the site at a level below ownership. Subsequently, in 2017, the contract for the decommissioning of the UK's first nuclear reactors was also cancelled (HC Deb 27 March 2017 c554WS).

This paper uses the Sellafield site as a case-study to explore why the contracting model for the nuclear legacy was not a success. This paper has two main aims; firstly, to analyse why simple state ownership and the privatisation of site management both faced problems; and, secondly to make wider points about the role of government in the nuclear legacy specifically, and in governance in general. To achieve these aims the first section explores the changing theory and practice of governance in contemporary society. The second section introduces the history of the nuclear legacy with specific reference to Sellafield, to place the paper its proper context. In the third section the changes to the governance of the nuclear legacy are analysed, from nationalised ownership through privatisation and the current hybrid system. The final section discusses why governance models for the nuclear legacy have changed and makes wider points regarding the role of government in the governance of the nuclear legacy specifically and in the governance of contemporary society in general.

\section{Rescaling governance}

Broadly defined, governance is "the means for authoritatively allocating resources and exercising control and co-ordination" (Rhodes 1996: 653). The overarching aim being 
"steering a society or polity" within a defined border (Lowndes 2001: 1961). Governance embraces "quasi- and non-state actors in a range of public-private partnerships" which can be characterised as the "shift from government to governance" (MacLeod and Goodwin 1999: 506). Thus, rather than a stark state/non-state or government/governance divide, the reality is of a continuum where a variety of systems of governing embrace various actors across sectors playing a diverse array of roles (Bulkeley 2005: 877; Kern and Bulkeley 2009: 311) and which "do not rest on a recourse to the authority and sanctions of government" (Wilson 2003: 318) but include government as an important player among a wider array of actors. This has "blurred" the boundaries between the state and market (Allen 2004: 29). In this context of a complex array of actors and functions characterising modern governance it is helpful to conceive of state power as a wide range of specific 'capabilities' (MacLeod and Jones 2007: 1187) which can be (temporarily) transferred to and exercised by non-state actors, where "it is not the national state as such, in its totality, but particular components that are undergoing denationalization" (Sassen 2008: 8). The partial denationalisation of the state as specific functions, or capabilities, which are transferred to the private sector results in the creation of markets, where previously there were none, which are neither fully public nor entirely private (Sassen 2008: 199). In the modern era therefore the state has withdrawn from certain functions, transferred others to private and other non-state actors, retained others and generally delivers functions in more complex ways which has led to different interpretations of the "new geography of governance" such as have variously been called 'glocalisation', or the 'hollowing-out' of the functions of the nation state (Bulkeley 2005: 882).

These changes in the way we are governed, enabled by technological and geo-political changes which removed limits upon the spatial expansion of markets and economic activity (Swyngedouw 1989: 35), is leading to increasingly fragmented sub-national places (Sassen 2008: 265). As a result, while the "discretionary powers of the state" to shape national economies has declined, the importance of local conditions increased (Swyngedouw 1989: 31). Thus, as a result of the "twin processes of rescaling" (Swyngedouw 2004: 25) the sub- 
national has become a key site for governance and economic activity in a heavily interconnected global system. The governance landscape is therefore "fragmented or 'splintered"' (Coaffee and Healey 2003: 1981) and local areas become "sites of power" (Held et al 1999: 28) where the different spatialities of the local and global interact (Sassen 2008: 394). The rescaling of elements of state authority which contribute to the rise in importance of sub-national scales of economic activity and regulation did not happen by accident, but involved "the necessary participation of national states" in rescaling elements of their "exclusive authority" (Sassen 2008: 5-6). This has led to a multi-level governance environment with a particular proliferation of a jurisdictions which are "flexible and task specific" with memberships which "criss-cross judicial boundaries" (Faludi 2012: 203). This is Type-Il multi-level governance (Marks and Hooghe 2004). One of the major drivers of Type-II governance is change in the way government exercises its authority through privatisation, outsourcing, administrative decentralization and other diversification of modes of governing (Marks and Hooghe 2004: 25). However, the assertion that this necessarily diminishes the role of government (Marks and Hooghe 2004: 25) is contested. Baker (2015: 250-251) argues that "the notion that government has become a diminished entity ... whose powers have been constrained or transferred" is overly simplistic and that government retains a "peculiar position" as "the actor of last resort who determines the rules of the game whilst guaranteeing the integrity of the network". Thus, "far from being a form of placeless power", authority has a complex spatiality where rather than power being "exchanged more or less in tact between scales" (MacLeod and Jones 2007: 1197) instead government has become "centralised yet dispersed" (Allen 2004: 27).

A weakness of multi-level governance is its poor account of "the practice of governance" which reveals the unique role government can still play (Baker 2015: 250). Over the course of the past 60 years, the way in which the state operates has changed. As markets have opened up, both public and private sectors have been affected. Public service was at one point thought of as a "Jesuitical corps' highly insulated from the general labour 
market", differentiated in the way it works, is paid, staff hired and promoted and is infused with a strong focus on hierarchy and generalised rules which limit discretionary power of public servants particularly in handing money, letting contracts and hiring where the 'Jesuitical corps' meets the 'corrupt world' (Osborne 2002: 14). The growth of traditional public administration, dominant in the very statist post-war years, seemed to be "the one thing certain about our future" (Schumpeter 1952: 294). However, forty years later the UK civil service was barely half the size and there was a "return to regulated private ownership for virtually all of its major public utilities" (Hood 1995: 165). New Public Management, which argued "for a public service less insulated from the private sector and for greater managerial discretion in the handling of staff and resources" (Hood 1995: 168) became dominant through the 1980s. NPM's key 'doctrines' (Hood 1991: 4-5) are consequently focussed on the import of private sector management into the public sector, particularly measuring outputs, competition to drive improvement and tight budgetary control. One key 'doctrine' is the "disaggregation" of the sector into discrete units, which can be measured, subject to competition and so on, essentially creating the conditions for a proliferation of Type-II multilevel governance structures. Thus, rather than the state simply withdrawing from certain areas, neither fully public nor entirely private hybrid 'markets' are created (Sassen 2008: 199). In practice, a salient example for nuclear decommissioning in the UK is the system for private involvement in the railway:

“... public ownership of the rail system in Britain has been replaced by private provision organized on a contractual basis with central government. This is Type II governance, not market competition. Central government remains accountable for the quality of service, but private firms contract with the government to provide it and, for the duration of the contract, they exercise considerable autonomous authority in doing so." (Marks and Hooghe 2004: 25) 
This combines features of a private market (freedom) with those of government (control). Depending on your perspective this could be a marriage of the best or worst elements of the public and private sectors. What is not in doubt is that market discipline does not necessarily in and of itself improve public services, as seen for railway infrastructure in the UK (Sassen 2008: 198).

In the shift from 'government to governance' government still has a range of 'tools' at its disposal to achieve its aims. The 'tools of government' approach (Hood 1986; Hood and Margetts 2007) proposes a framework of four 'tools' by which government achieves change: nodality, authority, treasure and organisation (NATO). Nodality involves information and the ability of government to persuade. Authority is the ability for government to arrange, instruct and enforce structures and rules. Treasure based tools, or "chequebook-government" (Hood 1983: 40) involve government incentivising actions. Finally, organisation tools relate to the ability of government to provide directly through, amongst other elements of state organisation, its "stock of people" (Hood 1983: 6). In a broad sense, the traditional public administration is reliant on 'organisation' tools whereas New Public Management focusses on treasury to achieve its aims. However, in both traditional public administration, with its emphasis on hierarchy and strong governmental control, and in the 'new public management' with its veneration of private sector management techniques, they both overrely on a limited, although different, range of 'tools'. For NPM in particular one-size fits all solutions in the application of market mechanisms to a diverse array of public policy areas is a common feature of their ultimate failure (Hood 1991: 3). Private involvement in the railway track, and also attempts to revive the nuclear power industry through incentivising private enterprise to build new stations in the 2000s (Baker 2015), are both demonstrative of this key issue in public sector reform in the UK.

\section{Background: Sellafield as the centre of the UK civil nuclear industry}


Sellafield is one of the largest nuclear sites in Europe and most complex nuclear sites in the world. Established following the Second World War on the site of a wartime Royal Ordinance Factory, Windscale (as Sellafield was known then) was one of the first nuclear installations in the UK and hosted the reactors and reprocessing facilities to create plutonium for the UK independent atomic weapons programme, made necessary following the United States' 1946 Energy Act which prohibited the sharing of atomic information. In the 1950s Calder Hall, the first commercial atomic power station in the world, was built and opened. In the 1960s the prototype for the UK's second generation electricity producing reactors, the Windscale prototype Advanced Gas Cooled Reactor (WAGR) was completed.

Reprocessing facilities for the fuel from the first generation atomic power reactors expanded. This all occurred under the United Kingdom Atomic Energy Authority (UKAEA), which was responsible for military and civilian atomic energy. However, as a consequence of the expansion of the nuclear industry, in 1967 the House of Commons Science and Technology Committee recommended the establishment of a dedicated production company to serve the fuel demand of the growing reactor fleet. The Atomic Energy Authority Act 1971 established British Nuclear Fuels Limited (BNFL), vesting the new organisation with the fuel cycle operations from the UKAEA. In these early days, through to the 1990 s, the majority of BNFLs activities were in Cumbria at the Windscale (now Sellafield) site, where the Calder Hall reactors, fuel reprocessing facilities and associated waste processing and management facilities were located, and to a lesser extent in Lancashire where the fuel fabrication took place (Springfields, near Preston) and BNFL's corporate headquarters were located (Risley, near Warrington).

In the thirty years following its creation, BNFL underwent considerable expansion. In Cumbria, significant additions included the construction of the Thermal Oxide Reprocessing Plant (THORP) and the Mixed Oxide (MOX) fuel manufacture facilities from the mid-1980s to late-1990s. Additionally, in the 1990s BNFL expanded internationally with the founding of a US-based decommissioning company BNFL Inc., the purchase of Westinghouse (the 
nuclear reactor supplier) and the predominantly Asian nuclear business of engineering conglomerate ABB. In addition to new ventures and acquisitions, in the 1990s BNFL was given responsibility for the first generation nuclear reactors. This was following the 1988 White Paper 'Privatising Electricity', which failed to privatise the entire nuclear fleet due to the costs of decommissioning and waste management particularly for the first generation reactors, and the generally favourable cost of coal, oil and gas generation at the time (HoC Research Paper 14/61 2014: 10). The transfer of the first generation reactors to BNFL enabled the more modern AGR and PWR reactors to be privatised as British Energy (Rhodes et al 2014: 10). BNFL was thus, at the turn of the millennium, involved in every stage of the nuclear fuel cycle around the globe. It is at this point, when BNFL was at its largest, that the general prospects for the nuclear industry globally were at their lowest (Nuttall 2004: 2) and BNFLs own end was only a few years away. At this point the days of "the research tail wagging the end-user's dog" (Welsh 1994: 43) were becoming a costly burden on the nuclear industry globally. The general trend of the time was to move from engineering-led innovation to de-regulate, contract out and move away from state provision (Nuttall 2004: 3). BNFL remained by the early-2000s as large, state owned fuel services business which increasingly had to face a challenge of cleaning up legacy facilities, particularly at Sellafield, which it was never set up for. At the time, the organisation also faced internal and external pressures, such as a scandal relating to falsification of data relating to fuel pellets manufactured at Sellafield, the commissioning and economics of a $£ 300$ million full-scale mixed-oxide (MOX) fuel facility, BNFLs more general costs and performance and poor public opinion of nuclear in general (Quint 2008: 668-9). In the 1990s the solution to these challenges, in the context of the previously proven unsuitability of a straightforward privatisation, was to bring private sector expertise and capital to BNFL through a Public Private Partnership (PPP). However, the PPP was delayed by government amid safety concerns at Sellafield (Morgan 2000) and eventually completely undermined by changes following the White Paper 'Managing the Nuclear Legacy' in 2002. 


\subsection{Establishing the NDA}

The government published a White Paper 'Managing the Nuclear Legacy: A Strategy for Action' in 2002 which outlined a new approach to management of the nuclear legacy. The underlying argument was that despite improvements at that time BNFL was not performing well enough either in managing historic liabilities or commercial activities (DTI 2002: 49). The high cost and financial risk of decommissioning, which had been the barrier to the privatisation of these early facilities in the 1980s (Rhodes et al 2014: 32), was only becoming more pressing as time passed. As it was clear that a straightforward privatisation of was not an option to which the markets would flock, a new governance arrangement for the nuclear legacy was required and the White Paper set out the approach to 'creating a market' for nuclear decommissioning in the UK. The new structure proposed to deal with the issue of cost and risk by splitting ownership from management, with the aim being to enable the creation of a competitive market for contracts to decommissioning sites (DTI 2002: 13). This drew heavily on the M\&O contracts which had been a common model for US nuclear sites ever since the industry was conceived.

The US experience with the development of atomic weapons was that it was not possible without the involvement of research institutions and private industry. The Manhattan project, through the Engineer Corps, used these contracts during the Second World War, and the 1946 Energy Act stated that the Atomic Energy Commission was required to draw upon all available expertise to fulfil its objectives, but in a way compatible with the US commitment to private enterprise and free markets, but with a government monopoly on fissile materials (DoE 2017: 2). The purpose being to facilitate long-term private management and operation of government owned facilities, which required two distinctive elements of $\mathrm{M} \& \mathrm{O}$ contracts; they do not specify detailed outputs, reflecting the unknown nature of research objectives 
which cannot be specified adequately early, and they are open-ended (extend or compete clauses) which means, should they be performing well, these contracts may roll on indefinitely. The US Supreme Court stated it was "virtually impossible to describe the contractual relationship in standard ... terms" because "while subject to the general direction of government, the contractors are vested with substantial autonomy" (DoE 2017: 5). While clearly intended to address the specific challenges of attempting to marry the certainty of a contract with the uncertainty of research, M\&O contracts do come with drawbacks. In 1994 the DoE was criticised for failing to hold these contracts sufficiently to account for performance, and consequently the DoE cut the number of these contracts and reformed the remaining ones (DoE 2017: 8). Despite reform, the central challenge of this type of contract will always be how to adequately specify and judge performance against unknown challenges and novel solutions. This M\&O model was the basis for the owner/operator relationship established in the UK following the 2002 White Paper and the same challenges were similarly relevant to the suitability of these types of contract for UK decommissioning.

The proposed structure guaranteed the state taking risk through ownership and funding, while the private sector management took risk with regards performance against a contract. The 2002 White Paper led to the establishment of the Liabilities Management Authority, which took ownership of sites from BNFL and UKAEA. The LMA became the Nuclear Decommissioning Authority following the Energy Act 2004. The task for the NDA was to achieve "safe, cost-effective, accelerated and environmentally responsible decommissioning" and this would be achieved by "creating competitive decommissioning and clean-up markets" (NDA 2006: 6). The creation of these markets involved a process of competitions for the shares in Site Licence Companies, and the management and operation of NDA owned sites. The transfer of shares in the SLC to the PBO, rather than awarding a management contract, is due to nuclear site licencing requiring the operator of the site to be the licence holder (CMA 2008). 


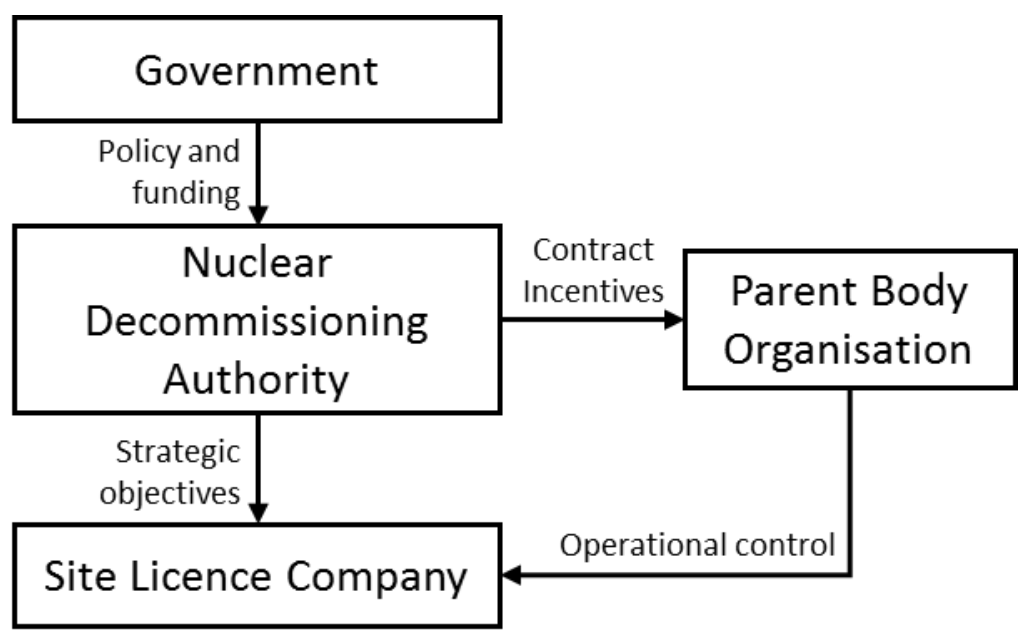

Figure 1 - NDA's first contracting model

\subsection{Contracting out the Sellafield Site}

Following the creation of the LMA and through the establishment of the NDA in 2005, the future arrangements for BNFL and UKAEA was to move into the private sector, and then potentially compete for the new contracts to operate the sites (DTI 2002: 13). The idea of public sector even being able to bid was not considered "appropriate" by government (DTI 2002: 50 ). For both BNFL the path to the private sector was not set in 2002 , but a publicprivate partnership (PPP) has been the preferred option for BNFL for some years (DTI 2002: 49-50). In parallel with the transfer of assets and liabilities to the LMA, and BNFL thus becoming a contractor, a joint review with the Department of Trade and Industry concluded there was significant value in BNFL for sale in parts, in particular those businesses overseas such as Westinghouse and the clean-up business in the USA, BNG America (formerly BNFL Inc.). This sale of large parts of BNFL meant that the remaining UK business, British Nuclear Group (BNG), would not according to the Government have "the required critical mass" for a PPP (HoC Deb 18 May 2006: C1179).

Following the establishment of the NDA in 2005, and in line with the timeframe in the 2002 White Paper, it was envisaged that competitions for site contracts would begin with the 
smallest site in 2006 (the Low Level Waste Repository) and leave Sellafield until 2012, after reprocessing the spent fuel from the UKs first generation of nuclear reactors was intended to be complete (NDA 2006: 12). However, the timescale for these sites had to be brought forward after the board of BNFL decided to break its UK business up rather than sell BNG whole (NDA 2007: 32). This decision by BNFL was problematic for the NDA as the timescale for site contracting was predicated upon the British Nuclear Group element of BNFL being sold as a single company, with a guaranteed initial five-year contract to manage the Sellafield site from 2007-2012 aimed at making the sale more attractive to potential private investors (Griffiths 2006). However, during the summer of 2006, the BNFL board decided to break up BNG and sell the assets off individually, due to fears that private companies interested in BNG, principally Fleur and Bechtel from the United States, were planning to buy BNG and then break it up themselves, making a significant amount of money (Parkinson 2006). The move to find a private-sector owner of the Sellafield Site Licence Company, British Nuclear Group Sellafield Limited (BNGSL) by competition was therefore precipitated by "the change in strategic approach by British Nuclear Fuels Limited (BNFL) regarding the future of British Nuclear Group Sellafield Limited (BNGSL)" (NDA 2007: 32). This led the NDA to "agree and favour an early competition for Sellafield" (NDA 2006: 151). Consequently the option was taken to bring forward from 2012 to 2007 the contract competition to find a Parent Body Organisation (PBO) for the Sellafield site.

The decision to let the contract for BNG Sellafield Ltd to a private company effectively ended the prospect of BNG competing for and undertaking work overseas (Griffiths 2006), which had been the intention since the 2002 White Paper (DTI 2002: 49). The new organisation, Sellafield Ltd, would become an arms-length subsidiary of other multi-national organisations. This was achieved in 2008, when the competition for the contract to own and manage Sellafield Ltd led to Nuclear Management Partners (NMP) being awarded a contract for up to seventeen years. NMP was a consortium of three large multi-national companies with significant experience in the nuclear industry set up specifically to bid for the contract for 
Sellafield Ltd. The three companies were, at the time, American company Washington Group (later URS and later still Aecom), British company AMEC (later Amec Foster Wheeler) and French company Areva.

The contract for management of the Sellafield site was supposed "to improve performance through innovation, greater incentive arrangements and a higher risk/reward profile" (NDA 2006: 63). For the NDA contractorisation would bring "UK and international best practice to bear on our mission" by "specifying the outcomes we seek rather than the work to be performed and rewarding cost effective delivery" (NDA 2011a: 13). For SLC contracts, which are "typically high value, high risk" contracts, the overarching aim is to maintain and enhance the capability of the SLC as an enduring entity (NDA 2011a:2.2) which aids later re-contracting and the long-term operation and safety of the sites. However, ownership of the SLC is intended to give the necessary level of control to provide the "direction, leadership and management" (NDA 2011a: 2.2) to implement significant change as envisaged by the PBO/SLC model (NDA 2013: 9). The NDA contracting principles actively encourage a significant level of control for the PBO over the SLC. The way in which contracts are let, particularly the high value and high risk critical contracts for site management, is intended to give the longest possible term and greatest possible freedoms within the constraints of ensuring operational endurance of the SLC, in line with the development of M\&O contracts in the US industry. The contracts thus have long durations and wide scope, specifically to give the PBO the greatest level of influence over the SLC (NDA 2011b: 2.3).

To incentivise the delivery of the contracting principles, the NDA employed what it termed "Trust with Consequences", which means that by default both internally and externally its stakeholders and suppliers are given "the responsibility, autonomy and authority within delegations to deliver the required performance in the way they see most appropriate" (NDA $2011 \mathrm{~b}: 2.4)$. The clear implication of the NDA approach to contracting and incentivisation is 
to give as great a scope as possible to the contractor in the day-to-day operation of their contracts for the longest practical time. In seeking to create and sustain a demand from suppliers to participate in the market for clean-up contracts, these principals and incentivisation methods make sense i.e. suppliers are more likely to bid for contracts where they are given certainty as to the funding. However, despite the wide scope granted in theory to the PBO by ownership and the secondment of senior management into the SLC, the contractual nature of the relationship meant the freedom was in practice very constrained to the extent that it was not possible, as was later separately confirmed by the experience of the early termination of the PBO contract for the Magnox sites decommissioning, to specify the contract to reflect the work required (HC Deb 27 March 2017, c 554WS).

The incentive based element of the fee structure of the PBO model has three main elements (NAO 2015: 18):

- Efficiency savings;

- Performance in meeting project milestones; and,

- Removal of work from the programme without affecting overall progress on the site. On the first category, while Sellafield did make considerable efficiency savings of $£ 715$ million over first five year period of NMP as the PBO, as compared to a target of $£ 699$ million (NAO 2015: 18), this came at a cost to meeting the second major incentive based fee category. NMP was criticised by consultants KPMG for the "undesirable consequences" of a focus on achieving short-term efficiencies at Sellafield which resulted in a "lack of focus on schedule performance, particularly for major projects" which "ultimately cost more than the efficiency savings" (KPMG 2013: 110). This criticism was confirmed and extended by investigations and reports from both the National Audit Office (NAO 2012; 2015) and the Public Accounts Committee (PAC 2013; 2015). The NAO noted that in the 2011/12 financial year only two of the NDA's 14 major projects at Sellafield were delivering as planned, incurring additional costs of £0.9 billion, far in excess of efficiencies achieved, costing NMP 
$£ 19$ million of their £74 million potential fee (NAO 2012: 8). However, overall costs rose for five key reasons including contractor capacity, pre-NDA issues around poorly designed facilities, and weak oversight by the NDA (NAO 2015: 8-10). However, the remaining two issues are more directly related to the structure of $M \& O$ type contracts and deserve more detailed consideration. Firstly, costs rose due to an inability to transfer risk to NMP as the owner, such that the NDA reimbursed all acceptable costs to Sellafield Ltd meaning that Sellafield does not bear risks and is less incentivised to avoid delays and cost increases (NAO 2015: 8). The remaining issue identified by the NAO relating to cost increases impacts on the fee structure of the PBO contract, and relates to poor cost and schedule estimation by Sellafield both during and before NMP's ownership. The final major element of the fee incentive was reducing the cost and complexity of the overall work programme, but the assumptions which underpinned the plan which NMP inherited proved to be inaccurate, and changes led to the total costs of the potential 17 year PBO tenure rising from $£ 18.2$ to $£ 24.6$ billion, and lifetime costs from £46.6 to £64.5 billion and further rises anticipated, but with little increase in ability and capacity to better estimate as a result of NMP ownership (NAO 2015: 7).

This final point relates to the capacity of Sellafield Ltd and returns this exploration of the governance of the nuclear legacy to where these changes began, the 2002 White Paper. The White Paper stated clearly that for the NDA, and wider new structure, performance and confidence were the two essential ingredients for success:

"The LMA will be publicly accountable for its performance and operate on an open and transparent basis. It will be judged not just on its operational performance and cost effectiveness but also on its ability to command public confidence." (DTI 2002: 13, emphasis added)

While NMP did made progress and efficiencies at Sellafield, there remained concerns in particular about the inability to improve the capacity of the site licence company (Clarke 
2014: 2). This raises on-going concerns for its ability to perform, on top of the already mixed performance of both NMP and the NDA as the accountable body, which would risk a breach of one of the conditions of the site licence granted by the Office for Nuclear Regulation, specifically condition 36 the "Organisational capability" of the licensee which states that "the licensee shall provide and maintain adequate financial and human resources to ensure the safe operation of the licensed site" (ONR 2016a: 22).

Wider ability to command public confidence was further eroded by a series of events which were smaller in scale and cost, but still damaging to the wider public perception. The House of Commons Committee on Public Accounts stated in 2013 that "we are not yet convinced that taxpayers are getting a good deal from the Authority's arrangement with Nuclear Management Partners" and singling out in particular "the costs of seconding staff from Nuclear Management Partners' parent companies" which the committee argued, after taking evidence, "appear excessively high, especially given the wage rates in the local economy" (PAC 2013: 3). This was further exacerbated by scandal surrounding the expenses paid to these seconded executives, which included a trip to the US Masters golf tournament, a taxi for one executive and their cat and company credit cards used for personal flights to the US by seconded executives, which was branded "a sickening waste of public money" by the local MP (BBC 2013).

\subsection{Market Enhanced Site Licence Company}

As with M\&O contracts in the USA, the PBO model in the UK did not remain static, with only the "small scale" and "simple" LLWR site remaining in its original form within the first ten years of these contracts being let (Clarke 2014: 2). The Sellafield PBO contract did not work, and was not modified, because the scope of the task was not specifiable and the SLC had major capability issues (Clarke 2014: 2). This would later prove to be the case at the Magnox sites, particularly in relation to the specification of the work required. At Sellafield 
the unsuitability of the PBO model was attributed by the NDA to the competition process by which the four potential PBOs were evaluated, which resulted in commitments being made which the NDA found were not able to be transformed into contractual commitments, and as a consequence these were not delivered (Clarke 2014: 5). The general thrust of the problem was that for one of the most complex nuclear sites in the world, and despite the NDAs original intention to specify "the outcomes we seek rather than the work to be performed" (NDA 2011: 13), a contractorised relationship between the site owner and the site operator was too restrictive. John Clarke, Chief Executive of the NDA when NMP lost their contract to operate Sellafield, said:

"The relationship between the NDA and Sellafield Ltd as a subsidiary will be more flexible than that which is based on a commercial contract. It will therefore be better able to cope with uncertainty and focus on long term outcomes." (Sellafield 2016: 11)

As explored earlier, the PBO model transfers significant power to the private sector. The NDA concluded that to transfer the entire scope of the operations of a site as large as Sellafield violated "good commercial practice" given that while the NDA has a sole purpose, to decommissioning its sites and site licence companies have a sole purpose to carry out the NDA mission at their site, the PBO could only be aligned with this in so far as it could be specified in a contract, which was not always possible (Clarke 2014: 5). Therefore, despite awarding NMP a second five-year instalment of their seventeen-year contract in 2013, only two years later in 2015 the NDA decided to terminate the NMP contract and alter the model for the management and operation for the Sellafield site to a 'Market Enhanced Model' (MEM) with effect from 1 April 2016 (NDA 2016). This new model simplified the ownership and operation of the Sellafield site by making the Site Licence Company, and therefore the workforce, a wholly owned subsidiary of the NDA. However, despite this return to complete public control, the NDA continued to believe that "private sector approaches and disciplines will add value" (Clarke 2014: 3) but through a "conventional" approach rather than the 
"bespoke PBO model" (Clarke 2014: 4). This 'conventional' approach means the private sector being engaged below the level of the SLC, either on site-wide strategic partnering arrangements or specific projects, rather than above it as owner and manager. This model has been used in the delivery of the 2012 Olympics and Crossrail, both very large infrastructure projects in London (NAO 2015: 25).

A key element of the new model is "workforce reform" (Clarke 2014: 5). New terms and conditions are being introduced which include lower pay and longer hours for new starters as well as other internal changes to pay, grading and so on (Sellafield Ltd 2016b: 26). The driver for this change is twofold: firstly, there is the imperative to reduce costs and increase productivity; secondly, and more significantly, the status of the site as a wholly owned subsidiary of the NDA places at risk exemptions which Sellafield has to wider public sector pay and conditions standards. These were, specifically, the Expenditure Review Group (ERG) Controls which aimed to reduce wasteful government spending, the public pay policy which deals with public sector workers' pay, and the caps placed on senior executive remuneration (Cabinet Office 2014). The outline business case for the MEM transition recognised that "increased proximity to government in the market enhanced SLC model" placed these exemptions at risk (NDA 2014b: 78). Specifically, the exemption on remuneration and pay had been based on Sellafield Ltd being in private sector ownership (NDA 2014b: 78). The specific case made for these exemptions to continue is redacted from the business case, but the implication is that these exemptions were only allowed on the basis of workforce reform:

It should be clear that the NDA is not seeking any further exemptions than those currently in place, and we fully understand the need to improve efficiency at Sellafield, including through workforce reform, which the NDA has committed to carry out within three years of model change (Clarke 2014: 5)

The new model, in bringing the site out of private ownership and into a closer relationship with government than it even had in the days of BNFL has therefore significant implications 
for the workforce, and consequently the wider community. The potential changes of workforce reform will be, as the local MP (at the time of model change) argued, "significant" and have a "ripple effect" due to the dominance of the site in the total local workforce (Sellafield 2016b: 37).

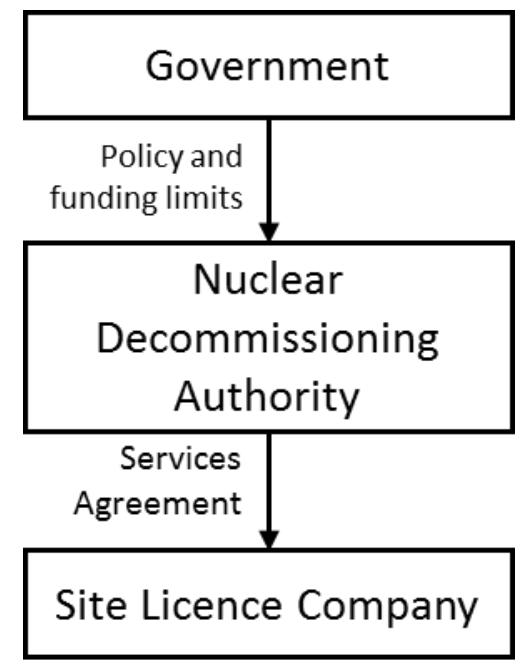

Figure 2 - The Market Enhanced Site Licence Company model

\section{Conclusion}

The problem with marketisation of ownership of the nuclear legacy at Sellafield stems ultimately from the very nature of the problem being addressed. The 'known unknowns' and 'unknown unknowns' inherent in decommissioning first of their kind, sixty-year-old nuclear facilities are ill-suited to being addressed by the SLC and PBO model. This model, driven by the need for the state to retain ownership of the sites and their associated risks (economic, in particular), constrained the way in which the private sector was engaged in the decommissioning challenge.

Given that the problem cannot be completely defined in advance, a contractual relationship which sets terms in stone at the outset of a relationship is challenging. While the model did explicitly attempt to grant the PBO the greatest possible freedom to act, ultimately if the 
scope of the work deviates from the terms of the contract with the NDA then the PBO has a duty to its shareholders to ensure the contract is varied and the payment reflect the work carried out. The rigidity of a contractual relationship was exacerbated, as the NDA recognised, by the scale at which private involvement was integrated into the governance of the nuclear legacy in the PBO model. The scope required of a contract covering such a diverse site as Sellafield proved near impossible to achieve. This difficult period of private sector ownership of the Sellafield site demonstrates the problems inherent with over-reliance on simplistic solutions. Contracting below the level of the site licence company has never been uncommon, particularly for civil engineering and construction. However, in the application of specific management and nuclear expertise to the general operation of the site, this was either fully nationalised under BNFL or fully contractorised under the PBO model. Placing the contractual relationship with the private sector for nuclear expertise between the site licence company the NDA, the government precluded itself from employing the full range of 'tools' at its disposal. Effective governmental control was not possible. What we see for the nuclear legacy, therefore, is not a privatisation or a marketization, nor a re-nationalisation, but the creation and ongoing modification of a Type-II multi-level governance system as part of the 'disaggregation' of the state. Despite the predictions of MLG, the state is not diminished by this change and its 'unique position' is clearly demonstrated.

A broader point this case demonstrates is that even for the broad conception of governance in contemporary society, embracing a diverse array of actors, government is not diminished and 'creating a market' does not necessarily mean 'withdrawing the state'. The problems resulting from an over-reliance on market mechanisms for the management of the Sellafield site was a result of the complexity and uncertainty of the site and the consequent inability to adequately specify a contract. While it might be tempting to fall back on government alone to operate the Sellafield site, past experience of nationalised ownership of UK industry, and the principle of over-reliance on any one model or tool caution against this simple solution. It 
may have been the case that, had BNFL not been broken up in 2006 and able to operate the Sellafield site as a nationalised company, but with the NDA as a customer in a newly competitive environment, their performance may have improved beyond 2007. The principle of the role of competitive contracts, market mechanisms and private sector involvement were not challenged by the experience of NMP, rather the challenge was to the governance architecture which placed these mechanisms at the inappropriate scale, as owner of the Site Licence Company. The PBO model was unsuitable because it maintained the worst aspects of BNFL as an arms-length company, the very much intended lack of effective state control (Rhodes et al 2014: 35), and added to it the difficulty of specifying and altering a contract in an environment of significant technical challenge (Clarke 2014), or 'known unknowns'. The direct control over the day-to-day running of the site being brought back under public control, but with greater market involvement than was the case under BNFL through strategic partnering at a level below the SLC, addresses this problem on paper and has successfully been deployed for large projects in the UK at the London Olympics and for Crossrail (NAO 2015: 25). Time will now tell if it can be made to work effectively, and potentially replicated for the other troubled contracts, for managing the UK nuclear legacy. 
Allen, J. (2004). The whereabouts of power: politics, government and space. Geografiska Annaler Series B, Human Geography, 86 (1): 19-32.

Baker, K. (2015), Metagovernance, Risk and Nuclear Power in Britain, in Edoardo Ongaro (ed.) Multi-Level Governance: The Missing Linkages (Critical Perspectives on International Public Sector Management, Volume 4) Emerald Group Publishing Limited, pp.247 - 269

BBC (2013) Sellafield expenses row prompts union call for inquiry. [Accessed 17/04/2018, available on-line http://www.bbc.co.uk/news/uk-england-cumbria-24008925]

Bulkeley, H. (2005) Reconfiguring environmental governance: Towards a politics of scales and networks. Political Geography 24: 875-902.

Cabinet Office (2010) The Coalition: Our Framework for Government. Accessed 23/05/2017, available online https://www.gov.uk/government/uploads/system/uploads/attachment_data/file/78977/coalition_pr ogramme_for_government.pdf]

Cabinet Office (2014) Efficiency and Reform Group. [Accessed 17/04/2018, available on-line https://www.gov.uk/government/organisations/efficiency-and-reform-group]

Clarke, J. (2014) Letter to Stephen Lovegrove, Permanent Secretary, from John Clarke, NDA CEO, on implementing market enhanced SLC at Sellafield: 17 December 2014. [Accessed 06 December 2016 available on-line https://tools.nda.gov.uk/publication/letter-to-stephen-lovegrovepermanent-secretary-from-john-clarke-nda-ceo-on-implementing-market-enhanced-slc-atsellafield-17-december-2014/] 
Coafee, J. and Healey, P. (2003) My voice, My place: Tracking transformations in urban governance. Urban Studies 40: 1979-1999.

Committee of Public Accounts (PAC) (2012) Nuclear Decommissioning Authority: Managing Risk at Sellafield. HC 746. London; The Stationary Office.

Committee of Public Accounts (PAC) (2014) Progress at Sellafield. HC 708. London; The Stationary Office.

Competittion and Markets Authority (2008) Nuclear Management Partners / Sellafield Ltd. [Accessed 24 May 2017, available on-line: https://www.gov.uk/cma-cases/nuclear-managementpartners-Itd-sellafield-Itd]

DBEIS (2016) Contract for Difference. Policy Paper [Accessed 23/05/2017, available online https://www.gov.uk/government/publications/contracts-for-difference/contract-for-difference]

Department of Energy (2017) The Origin, Characteristics, and Significance of the Department of Energy's Management and Operating (M\&O) Form of Contract [Accessed 17/04/2018, available on-line https://www.energy.gov/sites/prod/files/2017/02/^34/Acq\%20Guide\%2017602\%200rigin\%20Characteristics\%20and\%20Significance\%20of\%20DOE\%20Management\%20 and\%200perating\%20Contracts\%20Feb\%202017.pdf]

DTI (2002) Managing the Nuclear Legacy. London; The Stationary Office.

Faludi, A. (2012) Multi-Level (Territorial) Governance: Three Criticisms. Planning Theory and Practice 13 (2): 197-211.

Griffiths, I. (2006) Smoke and mirrors surround sale plan. The Guardian, Tuesday 18 April 2006. [Accessed 06 December 2016 available onlinehttps://www.theguardian.com/business/2006/apr/18/politics.nuclearindustry] 
Held, D., McGrew, A., Goldblatt, D. and Perraton, J. (1999) Global Transformations: Politics, Economics and Culture. Stanford, California; Stanford University Press.

Hood, C. (1983) The Tools of Government. London; Macmillan.

Hood, C.C. (1991) A Public Management for All Seasons? Public Administration 69: 3-19.

Hood, C. and Margetts, H. (2007) The Tools of Government in the Digital Age. London; Palgrave Macmillan.

Kern, K. and Bulkeley, H. (2009) Cities, Europeanization and Multi-level Governance: Governing Climate Change through Transnational Municipal Networks. JCMS 47 (2): 309-332.

KPMG (2013) The PBO model at Sellafield: Performance to 31st May 2013. [Accessed 17/04/18, available on-line http://www.nda.gov.uk/publication/kpmg-report-on-sellafield-performance-to-31may-2013/?download]

Lowndes, V. (2001) Rescuing Aunt Sally: Taking Institutional Theory Seriously in Urban Politics. Urban Studies 38 (11): 1953-1971.

MacLeod, G. and Goodwin, M. (1999) Space, scale and state strategy: rethinking urban and regional governance. Progress in Human Geography 23 (4): 503-527.

MacLeod, G. and Jones, M. (2007) Territorial, Scalar, Networked, Connected: In What Sense a 'Regional World'? Regional Studies, 41 (9): 1177-1191.

Marks, G. and Hooghe, L. (2004) Contrasting Visions of Multi-level Governance, in Bache, I. and Flinders, M. (eds.): Multi-level Governance. Oxford: Oxford University Press: 15-30. 
Myoshi, M. (1993) A Borderless World: From Colonialism to Transnationalism and the Decline of the Nations State. Critical Inquiry 19 (4).

NA0 (2012) Managing Risk at Sellafield [Accessed 17/04/18, available on-line

https://www.nao.org.uk/wp-content/uploads/2012/11/n1213630es.pdf]

NAO (2015) Progress on the Sellafield Site: An Update [Accessed 17/04/18, available on-line https://www.nao.org.uk/wp-content/uploads/2015/03/Progress-on-the-Sellafield-Site-anupdate.pdf]

NDA (2006) Strategy. [Accessed 06 December 2016 available onlinehttp://webarchive.nationalarchives.gov.uk/20080907083618/http://nda.gov.uk/documents/uplo ad/NDA_Final_Strategy_published_7_April_2006.pdf]

NDA (2007) Annual Report and Accounts 2006/7. [Accessed 06 December 2016 available onlinehttps://www.gov.uk/government/uploads/system/uploads/attachment_data/file/250541/1001.p df]

NDA (2011) Strategy. [Accessed 06/12/2016 available on-line at https://www.gov.uk/government/uploads/system/uploads/attachment_data/file/243549/97801085 10472.pdf]

NDA (2013) The NDA Operating Model: Guidance on the Roles of the Site Licence Company and the Parent Body Organisations (Rev 4). Doc No NSG 31. [Accessed 06 December 2016 available on-

linehttps://www.gov.uk/government/uploads/system/uploads/attachment_data/file/451752/NSG31 _The_NDA_operating_model_guidance_on_the_roles_and_the_Site_Licence_Company_and_th e_Parent_Body_Organisations.pdf] 
NDA (2016) Explained: the new model for managing Sellafield [Accessed 24 May 2017, available on-line https://www.gov.uk/government/publications/new-model-for-managingsellafield/explained-the-new-model-for-managing-sellafield]

Nuttall, W. (2004) Nuclear Renaissance: Technologies and Policies for the Future of Nuclear Power. London; Taylor and Francis.

Omahe, K. (1990) The Borderless World: Power and Strategy in the Interlinked Economy. London; HarperCollins.

Omahe, K. (1996) The End of the Nation State: The Rise of Regional Economies. London; HarperCollins.

Painter, J. (2010) Rethinking territory. Antipode: A Radical Journal of Geography 42: 1090- 1118

Quint, S.M. (2008) Sellafield to the States and back again The journey of BNFL and the effect on its in-house legal services. International In-house Counsel Journal 2 (5): 665-674

Rhodes, R.A.W. (1996) The New Governance: governing without Government. Political Studies 44 (4): 652-667.

Rhodes, C., Hough, D. and Butcher, L. (2014) Privatisation. Parliament, House of Commons Research Paper 14/61, 20 November 2014 [Accessed 23/05/17 available onlinehttp://researchbriefings.files.parliament.uk/documents/RP14-61/RP14-61.pdf]

Sassen, S. (2008) Territory, Authority and Rights: From Medieval to Global Assemblages. Woodstock; Princeton University Press. 
Sellafield Ltd (2016) Sellafield Magazine (Issue 03, April 2016) [Accessed 06/12/2016 available online http://www.sellafieldsites.com/wp-content/uploads/2016/04/Q3-Magazine_lo.pdf]

Swyngedouw, E. A. (1989). The heart of the place: the resurrection of locality in an age of hyperspace. Geografiska Annaler 71 (1): 31-42.

Swyngedouw, E. (2004) Globalisation or Glocalisation? Networks, Territories and Rescaling. Cambridge Review of International Affairs 17 (1): 25-48.

Urry, J. (2000 [2010]) Mobile Sociology. The British Journal of Sociology 61(S1) p347-366.

Welsh, I. (1994) Letting the research tail wag the end-user's dog: The Powell Committee and UK nuclear technology. Science and Public Policy 21 (1): 43-53.

Wilson, D. (2003) Unravelling control freakery: Redefining central-local government relations. The British Journal of Politics and International Relations 5 (3): 317-346. 